\title{
PENGARUH ACTIVITY RATIO, WORKING CAPITAL MANAGEMENT, FIRM SIZE DAN LEVERAGE RATIO TERHADAP PROFITABILITY PADA PERUSAHAAN SUB SEKTOR PROPERTY DAN REAL ESTATE YANG TERDAFTAR DALAM BURSA EFEK INDONESIA
}

\author{
Nadia Lionardi \\ Program Studi Magister Manajemen Universitas Tarumanagara \\ nadialionardi@gmail.com
}

\begin{abstract}
The purpose of this research was to determine the effect of activity ratio, working capital management, firm size and leverage ratio to company's profitability in sub sector property and real estate listed in Indonesia Stock Exchange. The sampling method was done by using purposive sampling. Secondary data collection methods were taken from IDX published financial statements. This research used multiple regression analysis with random effect method to test their hypothesis using Eviews 6. The results show that activity ratio, firm size and leverage ratio have a positive significant affect to company's profitability measured using ROE, while working capital management has a negative insignificant affect to company's profitability. F-test result show that all independent variables in this research simultaneously have a significant effect to company's profitability in sub sector property and real estate listed in Indonesia Stock Exchange. In the test of Adjusted $\mathrm{R}^{2}$, the analysis results showed that $39,83 \%$ profitability was influenced by the independent variables of this research while the remaining $60,17 \%$ influenced by other factors not studied.
\end{abstract}

Keywords : Activity Ratio, Working Capital Management, Firm Size, Leverage Ratio, Profitability.

\section{PENDAHULUAN}

Salah satu booming investasi yang berkembang pesat di Indonesia adalah investasi disektor property dan real estate. Banyak investor yang menginvestasikan modalnya di industri property karena harga tanah yang cenderung naik. Laju pertumbuhan bisnis properti dimulai pada tahun 2010 silam, dimana tahun tersebut menjadi fase awal bagi pertumbuhan bisnis properti untuk mengawali puncak kesuksesannya. Sektor industri property dan real estate merupakan sektor dengan karakteristik yang sulit untuk diprediksi. Dengan adanya pasang surut yang tidak tentu ini, maka dapat menyebabkan profitabilitas pada sektor property dan real estate menjadi berubah - ubah atau berfluktuatif. Rasio keuangan dapat digunakan sebagai alat untuk mengukur kinerja perusahaan, salah satu rasio yang dapat digunakan sebagai pengukuran kinerja keuangan adalah rasio profitabilitas. Profitabilitas suatu perusahaan dapat diukur dengan menghubungkan keuntungan yang diperoleh dari kegiatan pokok perusahaan dengan modal yang dimiliki untuk menghasilkan keuntungan perusahaan yaitu dengan return on equity.

Profitabilitas perusahaan dapat dipengaruhi oleh beberapa faktor diantaranya adalah activity ratio, dalam penelitian ini activity ratio diproksikan dengan total assets turnover. Alasan pemilihan rasio ini karena keefektifan perusahaan dalam menghasilkan penjualan dengan menggunakan aktivanya akan ditunjukkan melalui perhitungan total assets turnover.

Faktor yang juga mempengaruhi profitabilitas perusahaan adalah manajemen modal kerja (working capital management). Keberhasilan dalam pengelolaan akan modal kerja mencerminkan pengawasan yang maksimal terhadap aktiva lancar dan kewajiban lancar dalam meningkatkan profitabilitas yang dihasilkan dari efektifitas manajemen modal kerja. 
Working capital management dalam penelitian ini diproksikan dengan Working Capital Turnover (WCTO). Perusahaan yang memiliki ukuran yang lebih besar mempunyai pengaruh terhadap peningkatan profitabilitas perusahaan. Dengan mengkonversi total assets dalam logaritma, maka data dari total assets akan terdistribusi normal. Faktor lain yang mempengaruhi profitabilitas perusahaan adalah leverage ratio. Dalam penelitian ini leverage ratio diproksikan dengan Debt to Equity Ratio (DER). DER digunakan untuk mengukur kemampuan perusahaan dalam menutupi sebagian atau seluruh utang-utangnya baik jangka panjang maupun jangka pendek dengan dana yang berasal dari total modal.

\section{TELAAH KEPUSTAKAAN}

\section{Profitability}

Profitabilitas atau kemampuan memperoleh laba adalah suatu ukuran dalam presentase yang digunakan untuk menilai sejauh mana perusahaan mampu menghasilkan laba pada tingkat yang dapat diterima. Keberhasilan kinerja keuangan perusahaan dapat diukur dengan Return on Equity (Husnan, 2001). ROE menunjukkan kemampuan perusahaan untuk menghasilkan laba setelah pajak dengan menggunakan modal sendiri yang dimiliki perusahaan. Secara sistematis ROE dapat dirumuskan sebagai berikut:

$$
R O E=\frac{N E T I N C O M E}{\text { TOTALEQUITY }}
$$

Rasio ini penting bagi pihak pemegang saham untuk mengetahui efektivitas dan efisiensi pengelolaan modal sendiri yang dilakukan pihak manajemen perusahaan. Semakin tinggi rasio ini berarti semakin efisien penggunaan modal sendiri yang dilakukan manajemen perusahaan

\section{Activity Ratio}

Activity ratio digunakan untuk mengukur seberapa efektif perusahaan menggunakan aktiva yang dimiliki perusahaan. Rasio - rasio aktivitas dinyatakan sebagai perbandingan antara penjualan dengan berbagai aktiva pendukung terjadinya penjualan. Dari hasil pengukuran dapat terlihat apakah perusahaan lebih efisien dan efektif dalam mengelola asset yang dimilikinya atau mungkin justru sebaliknya. Rasio aktivitas yang digunakan dalam penelitian ini hanya Total Assets Turnover. Total Assets Turnover menurut Syamsuddin (2009), mengukur berapa kali total aktiva perusahaan menghasilkan penjualan. Total assets turnover dapat dihitung dengan menggunakan rumus:

$$
\text { TATO }=\frac{S A L E S}{\text { TOTALASSETS }}
$$

\section{Working Capital Management}

Setiap perusahaan selalu memerlukan modal kerja yang akan digunakan untuk membiayai kegiatan operasional perusahaan. Perusahaan mengeluarkan modal kerja diharapkan kembali masuk ke perusahaan dengan waktu yang singkat dari penjualan produksinya sehingga modal kerja terus berputar di perusahaan setiap periode (Riyanto, 2011).

Keberhasilan dalam pengelolaan akan modal kerja mencerminkan pengawasan yang maksimal terhadap aktiva lancar dan kewajiban lancar dalam meningkatkan profitabilitas yang dihasilkan dari efektifitas manajemen modal kerja. Dalam penelitian ini working capital management diproksikan dengan working capital turnover, yang secara sistematis dapat dirumuskan sebagai berikut :

$$
W C T O=\frac{S A L E S}{C A-C L}
$$




\section{Firm Size}

Ukuran perusahaan adalah suatu skala yang dapat diklasifikasikan besar kecil perusahaan menurut berbagai cara antara lain : total aktiva, log size, nilai pasar saham dan lain-lain (Suwito dan Herawaty, 2005). Ukuran perusahaan dapat diproksikan ke dalam logaritma natural dari total aktiva (Brigham \& Houston, 2001). Di mana penggunaan logaritma dimaksudkan untuk mengurangi fluktuasi nilai absolut dan mencegah terjadinya heteroskedastisitas, selain itu dengan mengkonversi total asset dalam logaritma, maka data dari total asset akan terdistribusi normal. Secara matematika firm size dapat dirumuskan sebagai berikut :

\section{Leverage Ratio}

\section{Firm size $=$ Log of Total Asset}

Salah satu faktor penting dalam unsur pendanaan adalah utang (leverage). Hutang merupakan salah satu aspek yang menjadi dasar penilaian bagi investor untuk mengukur kondisi keuangan. Leverage ratio penting bagi kinerja keuangan karena dalam mengembangkan perusahaan diperlukan sumber pendanaan. Sumber pendanaan dapat diperoleh dari dalam perusahaan maupun luar perusahaan. Debt to equity ratio merupakan ukuran pas yang dipilih untuk mewakili leverage ratio. Salah satu rasio yang diperhatikan oleh investor adalah DER, karena dapat menunjukkan komposisi pendanaan dalam membiayai aktivitas operasionalnya. Secara matematis DER dapat dirumuskan sebagai berikut :

\section{PENELITIAN TERDAHULU}

$$
D E R=\frac{T O T A L D E B T}{T O T A L E Q U I T Y}
$$

Penelitian yang dilakukan oleh Siahaan (2013), meneliti pengaruh firm size, firm age, capital structure, dan stock ownership terhadap profitability yang diproksikan dengan ROI dan ROE. Hasil dari penelitian ini menunjukkan bahwa firm size berpengaruh positif signifikan terhadap ROE. Penelitian lain yang dilakukan oleh Mou $\mathrm{Xu}$ dan Wanrapee Banchuenvijit dengan judul "Factors Affecting Financial Performance of Firms Listed on Shanghai Stock Exchange 50 (SSE 50)", hasil dari penelitian ini adalah assets utilization (total assets turnover) mempunyai pengaruh positif signifikan terhadap ROA dan ROE, leverage (debt ratio) mempunyai pengaruh negatif signifikan terhadap ROA dan ROE, firm size dummy negatif tidak siginifikan terhadap ROE.

Penelitian yang dilakukan oleh Warrad \& Omari (2015), meneliti pengaruh turnover ratio yang diproksikan dengan working capital turnover, total asset turnover dan fixed assets turnover terhadap profitability. Hasil dari penelitian ini adalah working capital turnover, total asset turnover dan fixed assets turnover tidak berpengaruh terhadap profitability. Penelitian yang dilakukan oleh Pratama (2013) menggunakan variabel dependen $R O E$ dan variabel independennya adalah equity multiplier, working capital turnover, dan size. Hasil dari penelitian ini adalah equity multiplier dan size berpengaruh signifikan terhadap ROE, working capital turnover tidak berpengaruh signifikan terhadap ROE. Penelitian lain yang dilakukan oleh Mule, Mukras dan Nzioka (2015), menggunakan variabel dependen profitability (ROA dan ROE) sedangkan variabel independen mengguunakan firm size, assets tangibility, financial leverage, ownership concentration, age of the firm dan management efficiency. Hasil dari penelitian ini adalah firm size berpengaruh positif signifikan terhadap terhadap ROE dan ROA, financial leverage berpengaruh negatif signifikan terhadap terhadap firm profitability. Penelitian yang dilakukan oleh Pongrangga, dkk (2015), mengambil sampel 35 perusahaan sub sektor property dan real estate dan hasil penelitian ini menunjukkan 
bahwa total assets turnover dan debt to equity ratio berpengaruh terhadap ROE secara parsial..

\section{HIPOTESIS PENELITIAN}

Hubungan antara variabel bebas dan variabel terikat digambarkan melalui model penelitian yang dapat dilihat pada gambar :

\section{Gambar 1 \\ Skema Kerangka Pemikiran}

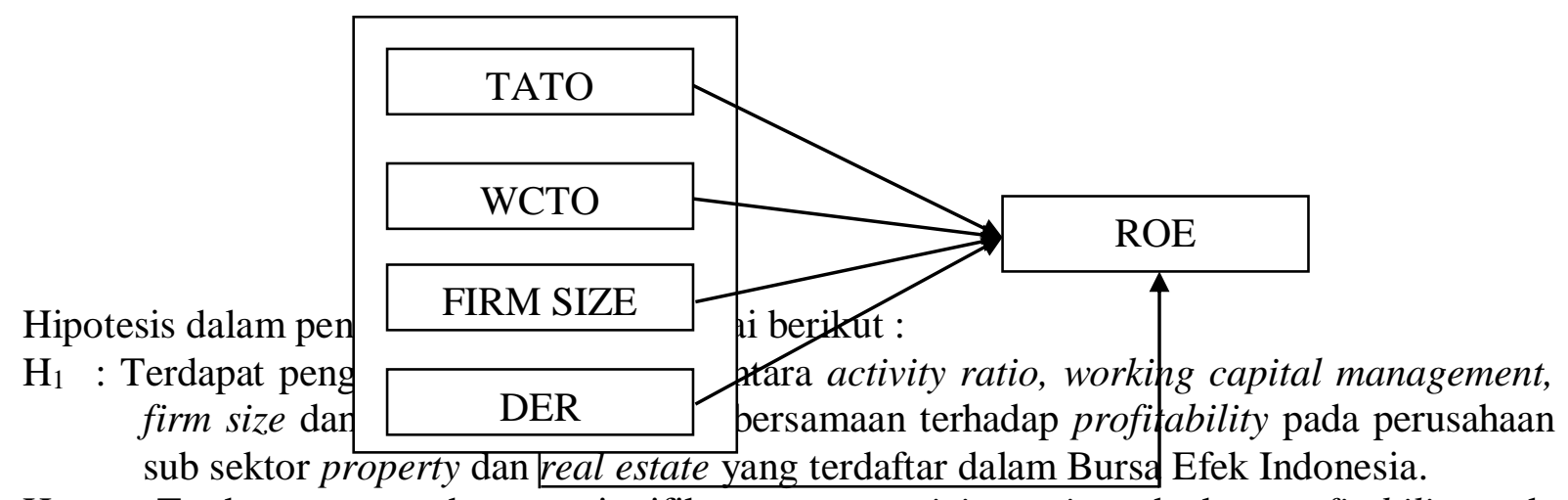

$\mathrm{H}_{2}$ : Terdapat pengaruh yang signifikan antara activity ratio terhadap profitability pada perusahaan sub sektor property dan real estate yang terdaftar dalam Bursa Efek Indonesia.

$\mathrm{H}_{3}$ : Terdapat pengaruh yang signifikan antara working capital management terhadap profitability pada perusahaan sub sektor property dan real estate yang terdaftar dalam Bursa Efek Indonesia.

$\mathrm{H}_{4}$ : Terdapat pengaruh yang signifikan antara firm size terhadap profitability pada perusahaan sub sektor property dan real estate yang terdaftar dalam Bursa Efek Indonesia.

$\mathrm{H}_{5}$ : Terdapat pengaruh yang signifikan antara leverage ratio terhadap profitability pada perusahaan sub sektor property dan yang terdaftar dalam Bursa Efek Indonesia.

\section{METODOLOGI PENELITIAN}

Jenis data yang digunakan dalam penelitian ini adalah data kuantitatif. Populasi dalam penelitian ini adalah seluruh perusahaan dalam sub sektor property dan real estate di Indonesia yang go-public dan terdaftar dalam Bursa Efek Indonesia (BEI) dari tahun 2011 sampai 2014. Metode dalam pemilihan sampel dilakukan berdasarkan metode Purposive Sampling. Beberapa kriteria yang ditetapkan untuk memperoleh sampel adalah perusahaan yang terdaftar dalam Bursa Efek Indonesia dan tergolong dalam sub sektor property dan real estate, perusahaan sampel menerbitkan laporan keuangan selama 4 tahun berturut-turut yaitu dari tahun 2011 sampai dengan 2014. Dari kriteria-kriteria tersebut diperoleh subyek penelitian sebanyak 40 perusahaan. Teknik analisis data menggunakan analisis linier berganda. Data yang diperoleh akan diolah dan dianalisis dengan menggunakan metode pengolahan data elektronik, yaitu dengan menggunakan software Eviews 6.

\section{HASIL DAN PEMBAHASAN}

\section{Analisis Regresi Linier Berganda}

Analisis regresi variabel dependen dan independen ini menggunakan Eviews 6 yang hasilnya dapat dilihat pada Tabel 1: 


\section{Tabel 1}

Analisis Linier Berganda

\begin{tabular}{crc} 
Variable & Coefficient & Prob. \\
\hline \hline C & -67.27700 & 0.0000 \\
TATO? & 0.450577 & 0.0000 \\
WCTO? & -0.000818 & 0.1097 \\
FIRMSIZE? & 0.050643 & 0.0000 \\
DER? & 0.063174 & 0.0005 \\
\hline \hline Adjusted R-squared & & 0.398335 \\
Prob(F-statistic) & & 0.000000 \\
\hline \hline
\end{tabular}

Sumber : Hasil pengolahan data menggunakan Eviews 6

Berdasarkan Tabel 1 dapat dibuat persamaan linier berganda sebagai berikut :

$\mathrm{Y}=-67,27700+0,450577$ TATO $-0,000818 \mathrm{WCTO}+0,050643$ SIZE + 0,063174 DER + 6,383894

Keterangan :

$\mathrm{Y} \quad=$ Return on equity

TATO = Total Assets Turnover

WCTO = Working capital turnover

SIZE $\quad=$ Firm size

DER = Debt to Equity Ratioz

Persamaan linier berganda di atas memiliki pengertian bahwa Return on Equity akan bernilai $-60,893106$ persen (yaitu $-67,27700$ persen ditambah dengan 6,383894 yaitu besarnya faktor-faktor lain diluar variabel independen yang diajukan dalam penelitian ini atau konstanta dan error dalam persamaan regresi jika variabel independennya sama dengan nol). Jika terjadi kenaikan satu persen pada total assets turnover dan variabel independen lainnya dianggap konstan, maka return on equity akan naik sebesar 0,450577 persen. Jika terjadi kenaikan satu persen pada working capital turnover dan variabel independen lainnya dianggap konstan, maka return on equity akan turun sebesar 0,000818 persen. Jika terjadi kenaikan satu persen pada firm size dan variabel independen lainnya dianggap konstan, maka return on equity akan naik sebesar 0,050643 persen. Jika terjadi kenaikan satu persen pada debt to equity ratio dan variabel independen lainnya dianggap konstan, maka return on equity akan naik sebesar 0,063174 persen.

\section{Pengujian Hipotesis}

Uji Hipotesis 1 (pengaruh activity ratio, working capital management, firm size dan leverage ratio secara bersamaan terhadap profitability (return on equity))

Dalam Tabel 1 dapat dilihat probabilitas untuk yang simultan sebesar 0.0000 yang berarti prob $<$ siginifikansi $(\alpha=0,05)$ maka Ho ditolak atau terdapat pengaruh yang signifikan antara activity ratio, working capital management, firm size dan leverage ratio secara bersamaan terhadap profitability pada perusahaan sub sektor property dan real estate yang terdaftar dalam Bursa Efek Indonesia.

Uji Hipotesis 2 (pengaruh antara activity ratio (total assets turnover) terhadap profitability )

Dalam Tabel 1 dapat dilihat nilai probabilitas untuk TATO sebesar 0.0000 yang berarti prob $<$ siginifikansi $(\alpha=0,05)$ maka Ho ditolak atau terdapat pengaruh yang siginifikan 
antara activity ratio terhadap profitability pada perusahaan sub sektor property dan real estate yang terdaftar dalam Bursa Efek Indonesia.

Uji Hipotesis 3 (pengaruh antara working capital management (working capital turnover) terhadap profitability )

Dalam Tabel 1 dapat dilihat probabilitas untuk WCTO sebesar 0.1097 yang berarti prob $>$ siginifikansi $(\alpha=0,05)$ maka Ho tidak ditolak atau tidak terdapat pengaruh yang siginifikan antara working capital management terhadap profitability pada perusahaan sub sektor property dan real estate yang terdaftar dalam Bursa Efek Indonesia.

Uji Hipotesis 4 (pengaruh antara firm size terhadap profitability)

Dalam Tabel 1 dapat dilihat probabilitas untuk SIZE sebesar 0.0000 yang berarti prob < siginifikansi $(\alpha=0,05)$ maka Ho ditolak atau terdapat pengaruh yang siginifikan antara firm size terhadap profitability pada perusahaan sub sektor property dan real estate yang terdaftar dalam Bursa Efek Indonesia.

Uji Hipotesis 5 (pengaruh antara leverage ratio (debt to equity ratio) terhadap profitability (return on equity) )

Dalam Tabel 1 dapat dilihat probabilitas untuk DER sebesar 0.0005 yang berarti prob < siginifikansi $(\alpha=0,05)$ maka Ho ditolak atau terdapat pengaruh yang siginifikan antara leverage ratio terhadap profitability pada perusahaan sub sektor property dan real estate yang terdaftar dalam Bursa Efek Indonesia.

\section{Nilai Koefisien Determinasi (Adjusted $\mathbf{R}^{2}$ )}

Hasil uji adjusted $\mathrm{R}^{2}$ untuk model analisis regresi dapat dilihat pada Tabel 1 di atas. Persamaan regresi linier berganda penelitian ini memiliki koefisien determinasi (Adjusted $R^{2}$ ) sebesar 0,3983 atau 39,83\% yang artinya sebesar 39,83\% variabel dependen yaitu profitability (return on equity) dapat dijelaskan oleh variabel independen, yaitu: dalam penelitian ini adalah activity ratio (total assets turnover), working capital management (working capital turnover), firm size, dan leverage ratio (debt to equity ratio) sedangkan sisanya sebesar $60,17 \%$ dapat dijelaskan oleh faktor-faktor lain yang tidak dimasukkan dalam penelitian ini

\section{KESIMPULAN DAN SARAN \\ Kesimpulan}

Maka kesimpulan yang dapat diambil dari penelitian adalah sebagai berikut :

1. Activity ratio, working capital management, firm size dan leverage ratio (debt to equity ratio) secara bersama-sama berpengaruh signifikan terhadap profitability pada perusahaan sub sektor property dan real estate yang terdaftar dalam Bursa Efek Indonesia.

2. Activity ratio, Firm size dan Leverage ratio secara parsial berpengaruh positif dan signifikan terhadap profitability sedangkan Working capital management secara parsial berpengaruh negatif dan tidak signifikan terhadap profitability pada perusahaan sub sektor property dan real estate yang terdaftar dalam Bursa Efek Indonesia.

\section{Saran}

1. Untuk penelitian selanjutnya, diharapkan menggunakan faktor-faktor lain yang belum dimasukkan dalam penelitian ini karena adjusted $\mathrm{R}^{2}$ dalam penelitian ini sebesar $39,83 \%$ dan sisanya sebesar $60,17 \%$ dipengaruhi oleh faktor - faktor lain yang artinya masih terdapat faktor-faktor lain di luar penelitian yang mungkin juga berpengaruh terhadap profitability.

2. Untuk manajemen perusahaan, perlu memperhatikan tingkat total assets turnover, debt to equity ratio, dan firm size karena variabel - variabel tersebut memiliki pengaruh yang 
signifikan terhadap profitabilitas perusahaan. Manajemen perusahaan juga diharapkan dapat mempertahankan atau bahkan meningkatkan hasil dari total assets turnover, debt to equity ratio, working capital turnover.

\section{DAFTAR KEPUSTAKAAN}

Ajija, S.R.,et al. (2011). Cara Cerdas Menguasai Eviews. Jakarta: Salemba Empat.

Arif, Syaiful, Raden R. Hidayat, Zahroh Z. A. (2015). Pengaruh Perputaran Modal Kerja, leverage, dan Pertumbuhan Penjualan Terhadap Profitabilitas. Jurnal Administrasi Bisnis (JAB), Vol.27 No.1, Oktober 2015. Administrasibisnis.studentjournal.ub.ac.id

Aritonang, R. Lerbin R. (2007). Teori dan Praktik Riset Pemasaran. Bogor: Ghalia Indonesia.

Brealey, Myres, dan Marcus. (2008). Dasar-dasar Manajemen Keuangan Perusahaan. Jilid 1. Jakarta: Penerbit Erlangga

Gitman, Lawrence J. (2006). Principles of Managerial Finance. $11^{\text {th }}$ Edition. Boston: Addison Wesley.

Husnan, Suad. (2001). Dasar - Dasar Teori Portofolio dan Analisis Sekuritas. Edisi Keempat. Yogyakarta: AMP YPKN. dan Enny Pudjiastuti. (2004). Dasar - Dasar Manajemen Keuangan. Edisi Keempat. Yogyakarta : UPP AMP YKPN.

Jumingan. (2009). Analisis Laporan Keuangan. Jakarta : Bumi Aksara.

Kasmir. (2009). Analisis Laporan Keuangan. Jakarta : PT. Raja Grafindo Persada. (2010). Pengantar Manajemen Keuangan. Jakarta: Kencana Prenada Media Group. (2011). Analisis Laporan Keuangan. Jakarta : PT. Raja Grafindo Persada.

Malhotra, NareshK. (2010). Marketing Research an Applied Orientation. New Jersey: Pearson.

Mardiyanto, Handoyo. (2009). Intisari Manajemen Keuangan. Jakarta: PT Grasindo

Mashady, Difky, Darminto, \& Ahmad Husaini. (2014). Pengaruh Working Capital Turnover (WCT), Current Ratio (CR), dab Debt to Total Asset (DTA) Terhadap Return on Investment (ROI) (Studi pada perusahaan Farmasi yang Terdaftar di Bursa Efek Indonesia Tahun 2009 - 2012). Jurnal Administrasi Bisnis (JAB), Vol.7 No.1, Januari 2014. Administrasibisnis.studentjournal.ub.ac.id

Mule, Dr. Robert K., Prof. M. S. Mukras dan O. M. Nzioka. (2015). Corporate Size, Profitability and Market Value: An Econometric Panel Analysis of Listed Firms in Kenya. European Scientific Journal. May 2015 Edition. Vol.11 No.13.

Pierre, Josee dan Josee Audet. (2011). Intagible Assets and Performance Analysis on Manufacturing SMEs. Journal of Intellectual Capital. Vol.12 No.2. Pp 202-223

Pongrangga, Rizki A., Moch. Dzulkirom dan M. Saifi. (2015). Pengaruh Current Ratio, Total Asset Turnover dan Debt To Equity Ratio Terhadap Return on Equity (Studi pada Perusahaan Sub Sektor Property dan Real Estate yang terdaftar di BEI periode 2011 2014). Jurnal Administrasi Bisnis Vol.25 No.2 Agustus 2015. administrasibisnis.studentjournal.ub.ac.id.

Pratama, Nur Edwin. (2013). Pengaruh Equity Multiplier, Working Capital Turnover dan Size Terhadap Return on Equity pada Perusahaan Aneka Insustri yang Terdaftar Di BEI Periode 2009 - 2012.

Purnomosidi, Lukman dkk. (2014). The Influances of Company Size, Capital Structure, Good Corporate Governance, Inflation, Interest Rate, and Exchange Rate of Financial Performance and Value of The Company. Interdisciplinary Journal of Contemporary Research In Business. Febuary 2014. Vol.5 No.10. ijerb.webs.com

Riyanto, Bambang. (2011). Dasar - Dasar Pembelanjaan Perusahaan. Edisi Keempat. Yogyakarta: Penerbit BPFE 
Sartono, Agus. (2011). Manajemen Keuangan Teori dan Aplikasi. Yogyakarta: BPFE

Sawir, Agnes. (2008). Analisis Kinerja Keuangan dan Perencanaan Keuangan. Jakarta : PT Gramedia Pustaka Utama

Siahaan, Fadjar O.P. (2013). Struktur Perusahaan dan Profitabilitas Pada Industri Real Estate dan Property di Indonesia. Jurnal Keuangan dan Perbankan. Vol.17 No.2 Mei 2013 hlm.192-199. http://jurkubank.wordpress.com

Sudarmadji, A. M. dan Lana Sularto. (2007). Pengaruh Ukuran Perusahaan, Profitabilitas, Leverage, dan Tipe Kepemilikan Perusahaan Terhadap Luas Voluntary Disclosure Laporan Keuangan Tahunan. Proceeding PESAT. Vol.2.

Sutrisno. (2009). Manajemen Keuangan Teori, Konsep dan Aplikasi. Edisi Pertama. Cetakan Ketujuh. Yogyakarta: Ekonisia.

Suwito, Edy dan Arleen Herawaty. (2005). Analisis Pengaruh Karakteristik Perusahaan Terhadap Tindakan Perataan Lana yang Dilakukan Oleh Perusahaan ynag Terdaftar Di Bursa Efek Jakarta. Simposium Nasional Akuntansi VIII. Solo

Syamsuddin, Lukman. (2009). Manajemen Keuangan Perusahaan: Konsep Aplikasi Dalam Perencanaan, Pengawasan, dan Pengambilan Keputusan. Edisi Baru. Jakarta: PT Raja Grafindo Persada

Van Horne, James C. and John M. Machowicz. (2005). Prinsip - prinsip Manajemen Keuangan. Buku Satu. Edisi Kedua Belas. Alih Bahasa oleh Dewi Fitriasari dan Deny Arnos Kwary. Jakarta: Salemba Empat

Warrad, Lina dan Rania Al Omari. (2015). The Impact of Turnover Ratios on Jordanian Service Sectors Performance. Journal of Modern Accounting and Audittung. February 2015, Vol.11 No 2, 77-85 doi:10.17265/1548-6583/2015.02.001

$\mathrm{Xu}$, Mou dan Wanrapee Banchuenvijit. Factors Affecting Financial Performance of Firms Listed on Shanghai Stock Exchange 50 (SSE 50) 


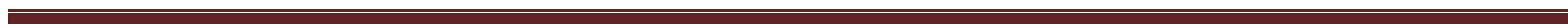
$\cdot$ 